\title{
PEMBEBAS DI ANTARA MEREKA YANG TERANCAM Mendialogkan Filosofi Ruwatan dengan Teologi Pendamaian dalam 1 Yohanes 2:2 dan 1 Yohanes 4:10
}

SRI SUWARNO

Universitas Kristen Duta Wacana, Yogyakarta

DOI: 10.21460/aradha. 2021.11.648

\begin{abstract}
The "ruwatan" ritual is a Javanese tradition that is still widely practiced in various regions. Many studies have been carried out by academics to examine the aspects contained in this tradition. This paper presents the analysis of the transcription of the "ruwatan" text performed by the puppeteer Ki Timbul Hadiprayitno to find the messages contained in it and then compared to 1 John 2: 2 and 1 John 4:10. The transcription of "ruwatan" by Ki Timbul Hadiprayitno was chosen because the script is complete and has been published. Meanwhile, the verses of 1 John 2: 2 and 1 John 4:10 were chosen because only these two verses in the New Testament contain the word "ruwat". The analysis was carried out on both sides, namely the whole transcription of "ruwatan" with its incantations and those verses by exploring the theological background that underlies these two verses' emergence. The word "ruwat" found in both verses is the equivalent

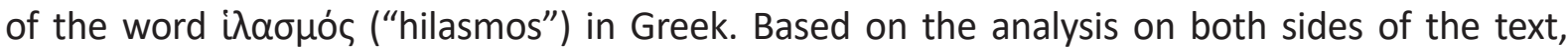
then the church's contextualization was determined. From the results of this study, it can be

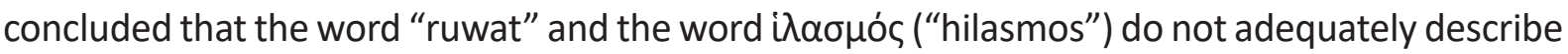
the work of Jesus as described in the text of 1 John. There is even a contradiction related to the violence that Batara Guru inflicts on humans compared to God's love for humans. Furthermore, it was found that the word "ruwat" for the equivalent of the word "hilasmos" was not entirely appropriate. However, there is an opportunity to use the "ruwatan" philosophy in introducing the redemptive work of Jesus based on the meaning of "hilasmos" in the text of 1 John.
\end{abstract}

Keywords: ruwat, ruwatan, hilamos, redemptive, 1 John 


\section{Abstrak}

Ritual ruwatan merupakan tradisi masyarakat Jawa yang masih banyak dilakukan di berbagai daerah. Banyak penelitian telah dilakukan oleh para akademisi untuk mengaji aspek-aspek yang terkandung dalam tradisi ini. Tulisan ini menyajikan analisis terhadap transkripsi teks ruwatan yang dipentaskan oleh dalang Ki Timbul Hadiprayitno untuk mencari pesan yang terkadung didalamnya, kemudian diperjumpakan dengan ayat 1 Yohanes 2:2 dan 1 Yohanes 4:10. Transkripsi dari pentas ruwatan Ki Timbul Hadiprayitno dipilih karena naskahnya lengkap dan sudah dibukukan. Sementara itu ayat-ayat 1 Yohanes 2:2 dan 1 Yohanes 4:10 dipilih karena hanya dua ayat inilah dalam Perjanjian Baru memuat kata ruwat. Analisis dilakukan pada kedua sisi, yaitu transkripsi ruwatan lengkap dengan mantra-mantranya dan ayat-ayat tersebut dengan menggali latar belakang teologi yang mendasari munculnya kedua ayat tersebut. Kata

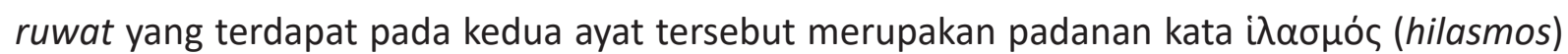
dalam bahasa Yunani. Berdasarkan analisis pada kedua sisi teks tersebut, selanjutnya diperjumpakan untuk mencari kontekstualisasinya dalam gereja pada jaman sekarang. Dari hasil penelitian ini dapat disimpulkan bahwa kata ruwat maupun kata i $\lambda \alpha \sigma \mu o ́ c$ (hilasmos) tidak sepenuhnya mengambarkan karya Yesus bagi manusia yang dijabarkan dalam teks 1 Yohanes. Bahkan ada kontradiksi terkait kekerasan yang dilakukan Batara Guru kepada manusia apabila dibandingkan dengan kasih yang diberikan Allah kepada manusia. Dari hasil analisis ini ditemukan bahwa pemilihan kata "ruwat" untuk padanan kata hilasmos sebenarnya kurang tepat. Namun demikian ada peluang untuk memakai filosofi ruwatan dalam memperkenalkan karya penebusan Yesus berdasarkan makna hilasmos dalam teks 1 Yohanes.

Kata-kata kunci: ruwat, ruwatan, hilasmos, pendamaian, 1 Yohanes

\section{Pendahuluan}

Tradisi ruwatan pada umumnya dilaksanakan oleh masyarakat di daerah-daerah Jawa Tengah, Yogyakarta dan Jawa Timur. Namun tradisi ini juga sering dibawa oleh orang Jawa yang merantau ke daerah atau wilayah lain di Indonesia. Tujuan utama mereka melaksanakan ritual ruwatan adalah membebaskan orang yang termasuk dalam kategori sukerta dari kutuk. Setelah menjalani ruwatan, mereka meyakini bahwa orang yang di-ruwat tersebut hidupnya akan lebih tenteram dan rejekinya juga akan lebih lancar. Meskipun tradisi ini sudah tidak banyak dilaksanakan oleh masyarakat secara pribadi, terutama karena pertimbangan biaya, namun masih sering dilakukan secara masal oleh lembaga atau institusi tertentu.

Tradisi ruwatan identik dengan pementasan wayang kulit dengan cerita Murwakala. Tidak diketahui secara pasti apakah tradisi ruwatan muncul berdasarkan cerita ini, atau 
sebaliknya cerita ini dibuat untuk kepentingan ruwatan. Dalam pelaksanaannya ritual ruwatan diintegrasikan dengan pementasan wayang kulit tersebut. Di bagian akhir pementasan cerita Murwakala ini, orang yang di-ruwat menjadi bagian atau pelaku cerita, begitu juga dalang ruwat akan berperan sebagai dalang Kanda Buwana, tokoh sentral dari cerita ini.

Tradisi ruwatan menjadi perdebatan diantara kalangan pemeluk agama karena mengandung filosofi pembebasan kutuk dan juga adanya sesaji dan mantra-mantra yang menyertainya. Berdasarkan fakta ini maka ada yang berpendapat bahwa tradisi ini bertentangan dengan ajaran agama. Namun ada juga yang menganggap bahwa tradisi ini tidak bertentangan dengan ajaran agama karena hanya merupakan bentuk budaya lokal. Menurut pendapat yang kedua ini, melaksanakan tradisi ruwatan hanyalah wujud pelestarian budaya.

Di kalangan umat Kristen sikap terhadap tradisi ruwatan juga tidak berbeda dengan sikap pemeluk agama pada umumnya. Pendeta Kristiyanto (2002), pernah meneliti sikap jemaat Gereja Kristen Jawa Margoyudan, Surakarta, terhadap tradisi ruwatan ini. Dari penelitian tersebut dilaporkan bahwa diantara 28 orang responden yang diwawancarai, $46,4 \%$ (13 orang) berpendapat bahwa penebusan Kristus sudah sempurna sehingga tidak perlu ada ritual tambahan apapun termasuk ruwatan. Responden sebanyak 35,7\% (10 orang) menyetujui adanya ritual ruwatan dengan alasan untuk menghargai tradisi, menghormati sikap keluarga yang masih mempercayai ruwatan dan sebagai wujud melestarikan budaya. Responden sisanya sebanyak 17,9\% (5 orang) bersikap netral. Meskipun penelitian sejenis belum diadakan pada jemaat-jemaat di gereja lain, namun cukup memberi gambaran bahwa sikap itulah yang ditunjukkan oleh orang Kristen pada umumnya.

Umat Katolik pada umumnya lebih terbuka terhadap tradisi ruwatan. Kustono (2006:7577) menganalisis tradisi ruwatan dengan acuan Alkitab. Menurut Kustono ada makna yang dapat digali dari tradisi ruwatan, misalnya tentang konsep keselamatan, nilai etika hubungan suami isteri, memahami Sang Waktu, penyucian dan pembersihan, tanggung jawab orang tua terhadap anak, makna sesaji, dan makna kidung dan mantra yang ada dalam tradisi tersebut. Dalam tulisannya ia juga membahas tata cara ruwatan Katolik yang disusun oleh Romo A. Sandiawan Brata Pr. (dalam Kustono, 2006:77-78), yang menyebutkan bahwa yang perlu diruwat adalah mereka yang lemah jiwanya, mudah terkena godaan dan bahkan memberontak terhadap kehendak Allah. Dengan demikian menurut Romo A. Sandiawan Brata Pr., mereka yang disebut sukerta adalah mereka yang harus bertobat. Dalam tata cara ruwatan Katolik ini tradisi ruwatan tradisional dimodifikasi dengan tradisi gereja, salah satunya adalah mantramantranya diganti dengan ayat-ayat Alkitab, misalnya Yohanes 17.

Kata "ruwatan" berasal dari kata dasar "ruwat" yang artinya luwar saka panenung, luwar saka ing bebendhu paukumaning dewa (Kamus Bahasa Jawa, 2011:628), (terbebas dari tenungan, terbebas dari kutuk hukuman dewa), sedangkan kata "ruwatan" artinya slametan kanggo ngruwat (upacara selamatan untuk me-ruwat). Dalam Kamus Besar Bahasa Indonesia 
(KBBI) online, kata ruwatan berarti upacara membebaskan orang dari nasib buruk yang akan menimpa (https://www.kbbi.web.id/ruwat).

Dalam Kitab Suci (Alkitab Bahasa Jawa) terbitan LAI tahun 1981, kata yang berasal dari kata "ruwat" hanya ditemukan pada dua ayat, yaitu 1 Yohanes 2:2 dan 1 Yohanes 4:10.

Lan Panjenengané iku kang dadi pangruwaté dosa kita, lan ora ngemungaké dosa kita baé, nanging malah iya dosané wong sajagad kabèh. (1 Yokanan 2:2)

Katresnan iku mangkené: Dudu kita kang wus padha tresna marang Gusti Allah, nanging Gusti Allah kang wus nresnani kita lan wus ngutus Kang Putra minangka pangruwating dosa kita. (1Yokanan 4:10).

Arti dari "pangruwate" maupun "pangruwating" pada kedua ayat tersebut adalah sama, yaitu "pribadi yang menjalankan ruwat". Dalam Akitab bahasa Indonesia terbitan LAl tahun 1974, kedua kata ini diterjemahkan "pendamaian". Kata "pangruwat" dan juga "pendamaian" ini merupakan padanan kata ið $\alpha \sigma \mu$ ó (hilasmos) dalam bahasa Yunani. Penulis berasumsi bahwa para penerjemah sudah memikirkan secara matang ketika memutuskan untuk memilih kata "pangruwate" untuk padanan kata hilasmos. Alasan inilah yang mendorong penulis untuk mendialogkan antara filosofi yang ada dalam tradisi ruwatan dengan kedua ayat diatas.

\section{Sinopsis Singkat Cerita Murwakala}

Secara garis besar cerita Murwakala dapat dibagi menjadi dua sub-cerita, yaitu cerita lahirnya Batara Kala dan cerita proses munculnya ruwatan. Pada umumnya para dalang ruwat menceritakan lahirnya Batara Kala dalam bentuk kilas balik (flashback) untuk menyingkat durasi pementasan.

Batara Kala adalah raksasa pemakan manusia dan merupakan tokoh utama dalam cerita Murwakala, selain tokoh dalang Kanda Buwana. Subalinata dkk. (1985:34-40), mengumpulkan kisah Batara Kala dari sejumlah literatur, diantaranya Serat Manikmaya IX-X, Serat Pakem Pangruwatan Murwakala dan Sarasilah Wayang Purwa. Meskipun ada sedikit perbedaan diantara sumber-sumber tersebut, namun secara garis besar cerita lahirnya Batara Kala dapat diringkas sebagai berikut.

Batara Guru disebut juga dengan nama Hyang Girinata adalah raja dari para dewa dan memiliki isteri namanya Dewi Uma. Suatu hari Batara Guru mengajak isterinya keliling dunia dengan naik lembu Andini, yaitu sapi yang merupakan kendaraan Batara Guru. Lembu Andini ini berjenis kelamin ganda dan memiliki kesaktian sehingga dapat terbang meskipun tidak memiliki sayap. Dalam perjalanan keliling dunia itu mereka sampai di atas pulau Jawa dan waktunya senja hari. Oleh karena melihat suasana senja yang indah tersebut Batara Guru timbul berahi dan ingin bercinta dengan isterinya meskipun sedang berada di punggung lembu 
Andini. Dewi Uma menolak keinginan Batara Guru, namun karena suaminya sudah terlanjur berahi maka spermanya tumpah dan jatuh ke samudera. Dewi Uma menanggapinya dengan berkata kasar bahwa Batara Guru kelakuannya mirip raksana. Akibat perkataan itu terjadilah pada Batara Guru tumbuh taringnya.

Masuknya sperma Batara Guru ke dalam samudera menimbulkan kejadian yang menggemparkan karena sperma tersebut berubah menjadi benda panas yang bersinar dan mengaduk-aduk samudera. Kegemparan itu sampai di kahyangan dimana para dewa bersemayam. Batara Guru memerintahkan para dewa supaya mencari sumber kegemparan dan menghancurkannya. Anehnya ketika benda tersebut dihujani senjata para dewa, justru berubah menjadi raksasa sebesar gunung. Raksasa tersebut berbalik dan mengejar para dewa yang lari tunggang langgang kembali ke kahyangan. Raksasa tersebut terus mengejar mereka dan akhirnya bertemulah dengan Batara Guru.

Kepada Batara Guru ia menanyakan siapa ayahnya. Atas pertanyaan ini Batara Guru bersedia memberitahu siapa ayahnya dengan syarat raksasa tersebut mau mencium kakinya. Raksasa tersebut sanggup, dan sewaktu mencium kaki Batara Guru, rambut di kedua pelipisnya dicabut sehingga ia meronta. Pada waktu meronta itulah kemudian ujung kedua taringnya dicabut oleh Batara Guru sehingga kekuatannya hilang. Selanjutnya Batara Guru memberitahu bahwa ia adalah anaknya dan diberi nama Batara Kala. Batara Guru memerintahkan supaya Batara Kala tinggal di Nusakambangan dan merajai semua makluk jahat dan jin yang tinggal di pulau Jawa. Batara Kala menuruti perintah Batara Kala tetapi minta jatah makanan berupa manusia. Batara Guru menyetujui permintaan Batara Kala tetapi hanya manusia dengan kriteria sukerta dan sengkala yang boleh dimakan. Manusia disebut sukerta berdasarkan jumlah saudara kandung dalam satu keluarga, sedangkan manusia disebut sengkala apabila melakukan sesuatu yang tabu.

Setelah Batara Kala pergi, Batara Guru ingat bahwa dewi Uma pernah berkata kasar kepadanya yang membuatnya memiliki taring seperti raksasa. Oleh karena itulah Batara Guru marah dan mengutuk Dewi Uma menjadi raksasa dan diberi nama Dewi Durga. Selanjutnya Dewi Durga diusir dari kahyangan dan disuruh ke Nusakambangan bersama Batara Kala.

Kisah kelahiran Batara Kala disambung atau dikaitkan dengan kisah munculnya tradisi ruwatan. Subalinata dkk. (1985:45-87) mengumpulkan sejumlah sumber literatur yang memuat kisah ruwatan ini, diantaranya kitab Centhini karangan Sunan Pakubuwana V, buku Pakem Pangruwatan Murwakala karangan Kyai Demang Reditanaya, buku karangan Raden Mas Citrakusuma, buku Serat Pedalangan Ringgit Purwa karangan KGPAA Mangkunegara VII dan buku Pakem Lakon Wayang Purwa karangan Riyasudibyaprana. Seperti halnya kisah kelahiran Batara Kala, masing-masing sumber tersebut juga memiliki sejumlah perbedaan detail cerita. Namun secara garis besar kaitan kelahiran Batara Kala dengan tradisi ruwatan dapat dirangkum 
sebagai berikut. Rangkuman ini juga didasarkan pada transkripsi pentas ruwatan oleh Ki Timbul Hadiprayitno yang sudah dibukukan oleh Sri Teddy Rusdy (2012:65-130).

Batara Narada, yaitu perdana menteri para dewa, protes kepada Batara Guru, terkait keputusannya mengijinkan Batara Kala memangsa manusia sebagai makanannya sehari-hari. Kalau keputusan tersebut tidak diubah, maka manusia di dunia akan habis dimakan Batara Kala. Menanggapi protes ini, Batara Guru membuat semacam rekayasa supaya kerakusan Batara Kala dalam memakan manusia dapat diatasi. Untuk maksud ini Batara Guru dan beberapa dewa sengaja melakukan perjalanan pada waktu tengah hari. Perjalanan ini termasuk sengkala, maka perjalanan mereka dicegat oleh Batara Kala. Dalam pertemuan antara Batara Kala dan rombongan para dewa inilah terjadi rekayasa tersebut.

Batara Guru mengijinkan Batara Kala memakan manusia tetapi dengan syarat tambahan, yaitu selain kriteria sukerta dan sengkala, mereka yang akan dimakan harus dipotong dengan pedang khusus pemberian Batara Guru dengan nama pedang Sukayana. Selain itu Batara Guru memberi tulisan rahasia pada bagian-bagian tubuh Batara Kala, yaitu bagian dahi, bagian langitlangit mulut dan bagian dada dan punggungnya. Isi atau makna dari tulisan rahasia tersebut sebenarnya merupakan rangkaian kisah lahirnya Batara Kala. Batara Guru memberitahu Batara Kala bahwa tidak ada orang yang tahu makna tulisan-tulisan tersebut kecuali orang yang ilmu kesaktiannya melebihi Batara Kala. Oleh karena itu apabila ada orang yang dapat membaca dan mengartikan tulisan-tulisan tersebut, maka Batara Kala harus tunduk dan mentaati segala perintahnya. Batara Kala setuju dengan semua syarat yang diberikan Batara Guru dan kemudian mereka berpisah.

Rekayasa Batara Guru berlanjut dengan cara menyamar menjadi manusia yang profesinya sebagai dalang ruwat dengan nama dalang Kanda Buwana. Penyamaran ini tentu ada maksud bahwa hanya dialah yang tahu makna tulisan-tulisan rahasia pada bagian-bagian tubuh Batara Kala. Para dewa yang menyertai Batara Guru juga menyamar menjadi para penabuh gamelan atau pemain musik dalam pentas ruwatan.

Pada suatu hari ada kepala dusun yang mengadakan acara ruwatan untuk me-ruwat desanya. Diundanglah dalang Kanda Buwana untuk melaksanakan pentas ruwatan di rumahnya. Pada waktu pentas inilah Batara Kala datang karena manusia yang akan dimakannya lari dan bersembunyi di belakang dalang Kanda Buwana. Dari kejadian inilah terjadi dialog tawar menawar antara Batara Kala dengan dalang Kanda Buwana. Dalam dialog ini mereka mengadu ilmu, siapa yang lebih tinggi. Dari adu ilmu ini dalang Kanda Buwana berhasil mengungguli Batara Kala dan juga berhasil membaca seluruh tulisan rahasia pada bagian-bagian tubuh Batara Kala. Dengan demikian Batara Kala mengaku kalah dan bersedia menuruti perintah dalang Kanda Buwana. Di akhir cerita, Batara Kala bersedia di-ruwat oleh dalang Kanda Buwana dan dikembalikan menjadi dewa serta dikembalikan ke kahyangan. Selain Batara Kala, Dewi 
Durga dan para makluk jahat pengikutnya juga di-ruwat. Selesai menjalankan tugas ruwatan, dalang Kanda Buwana dan para penabuh musiknya mengakhiri penyamarannya dan kembali ke kahyangan. Dalam pementasan cerita Murwakala ini, sejumlah simbol digunakan atau disertakan dan memiliki makna filosofis dari tradisi ruwatan.

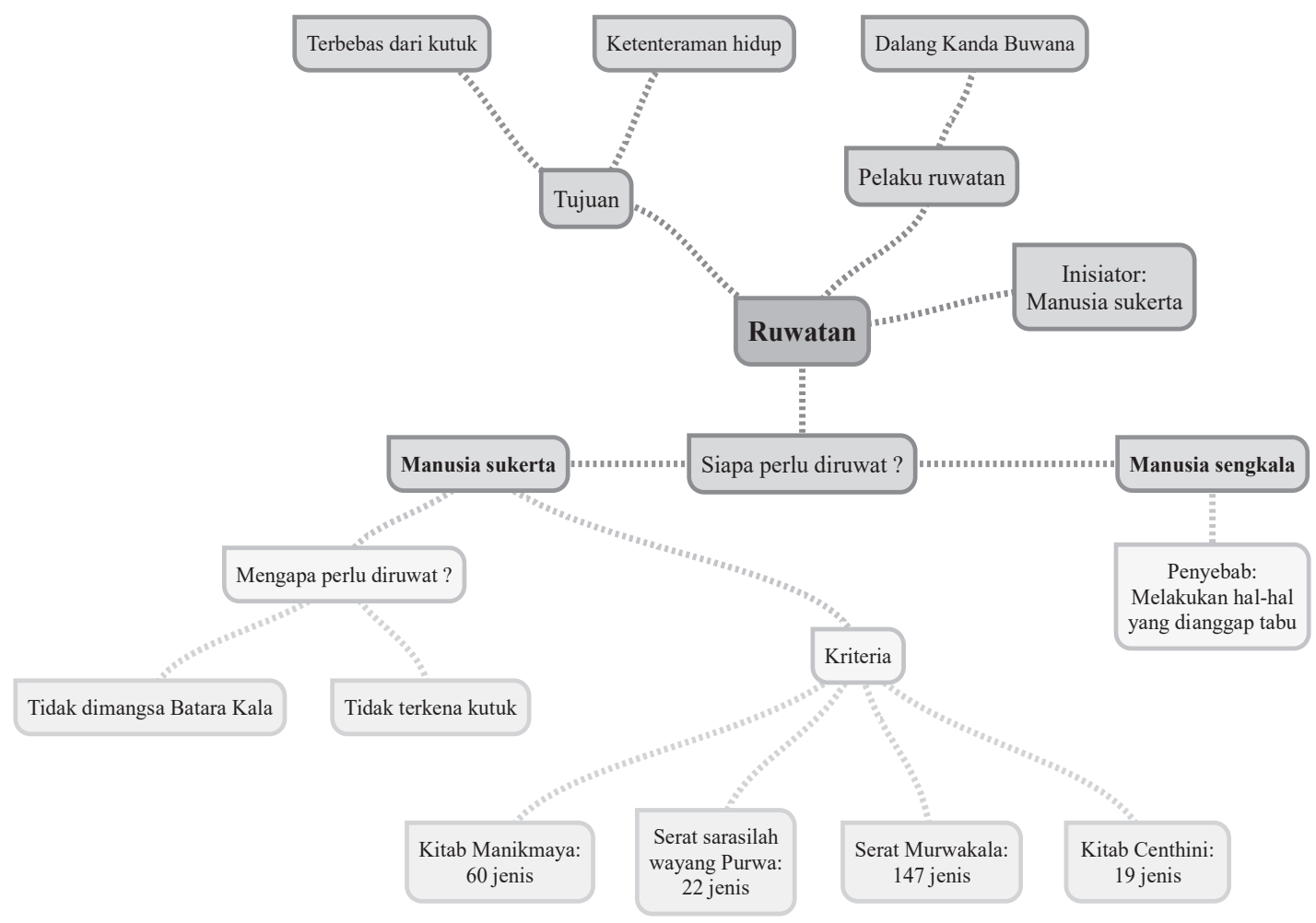

Gambar 1. Mindmap Ruwatan

\section{Filosofi dalam Tradisi Ruwatan}

Relin (2015:72-73) menyatakan bahwa filosofi tradisi ruwatan terletak pada tahapan-tahapan upacaranya, yang meliputi siraman (memandikan orang yang akan di-ruwat), sesaji dan selamatan, penyerahan sarana berupa barang-barang simbolis kepada dalang ruwat, potong rambut, tirakatan (ritual tidak tidur semalaman) dan juga nama-nama alat musik (gamelan) yang digunakan. Namun karena tulisan ini hanya menoroti tradisi ruwatan dari segi transkripsi teks cerita Murwakala, maka filosofi yang dibahas terutama adalah isi ceritanya.

Tradisi ruwatan memiliki sejumlah aspek yang menyertainya yang secara sederhana dapat digambarkan dalam bentuk maindmap seperti terlihat pada Gambar 1. Seperti terlihat pada gambar tersebut bahwa tujuan utama mengadakan ruwatan adalah untuk membebaskan para sukerta dari kutuk sehingga hidupnya akan lebih tenteram. Dalam cerita Murwakala, bentuk kutuk yang akan diterima para sukerta yang tidak di-ruwat adalah 
dimakan Batara Kala. Supaya mereka tidak dimakan Batara Kala mereka harus mendatangi orang yang mampu me-ruwat dengan membawa sejumlah syarat. Masyarakat yang meyakini tradisi ruwatan menafsirkan bahwa bentuk kutuk yang diterima adalah kehidupan rumah tangga yang terganggu, hubungan antar anggota keluarga yang tidak harmonis, terkena sakit penyakit dan juga terkait rejeki yang tidak lancar.Oleh karena tujuan ruwatan adalah pembebasan kutuk, maka harus dilakukan atau dipimpin oleh orang dengan kriteria tertentu. Adapun orang yang dianggap mampu melaksanakan ruwatan adalah dalang ruwat yang memenuhi sejumlah kriteria yang cukup berat. Kriteria tersebut diantaranya adalah memiliki darah keturunan dalang ruwat, baik dari jalur silsilah dalang yang bersangkutan maupun dari jalur silsilah isterinya. Dengan syarat ini dalang ruwat harus sudah memiliki isteri dan isterinya harus masih hidup. Syarat lain yang dianggap cukup berat adalah dalang ruwat harus memiliki ilmu yang memadai karena harus membaca mantra-mantra yang dianggap memiliki kekuatan magis. Selain itu, ketika sedang memimpin upacara ruwatan, dalang ruwat pada adegan tertentu akan menjadi dalang Kanda Buwana yang merupakan penjelmaan Batara Guru yang harus me-ruwat Batara Kala.

Disamping syarat-syarat tersebut, secara teknis dalang ruwat harus hafal mantra ruwatan yang panjang dan sulit dimengerti artinya, meskipun pada jaman sekarang teks mantra-mantra tersebut dapat ditulis dan dibaca. Namun "wibawa" dalang ruwat akan berkurang apabila dia membaca mantra dari teks tertulis. Secara umum dalang ruwat biasanya sudah tua dan sangat dihormati di masyarakat.

Tabel 1. Jenis dan Sumlah Sukerta

\begin{tabular}{|l|c|}
\hline \multicolumn{1}{|c|}{ Sumber } & Jumlah Sukerta \\
\hline Serat Murwakala & 147 \\
\hline Kitab Centini & 19 \\
\hline Serat Sarasilah Wayang Purwa & 22 \\
\hline Kitab Manikmaya & 60 \\
\hline
\end{tabular}

Kriteria manusia yang temasuk sukerta cukup beragam tergantung acuan atau literatur yang digunakan. Tabel 1 merangkum banyaknya kriteria sukerta dari berbagai sumber. Berdasarkan angka-angka pada tabel tersebut sangat dimungkinkan kalau sebagian besar orang akan termasuk manusia yang sukerta. Hal inilah yang menurut penulis penyelenggarakan ruwatan masal banyak diikuti oleh masyarakat yang merasa dirinya perlu di-ruwat. Dengan demikian ide atau inisiatif untuk di-ruwat adalah orang yang bersangkutan atau dari pihak keluarganya. Filosofi yang terkandung dalam tradisi ruwatan inilah yang akan didialogkan dengan teologi pendamaian dalam 1 Yohanes 2:2 dan 1 Yohanes 4:10. 


\section{Teologi Pendamaian dalam 1 Yohanes 2:2 dan 4:10}

Seperti sudah disinggung di bagian awal tulisan ini, kata yang berasal dari kata dasar "ruwat" hanya ditemukan pada 1 Yohanes 2:2 dan 1 Yohanes 4:10. Kata ini dalam Alkitab Bahasa Indonesia terbitan LAI diterjemahkan dengan kata "pendamaian".

Dan la adalah pendamaian untuk segala dosa kita, dan bukan untuk dosa kita saja, tetapi juga untuk dosa seluruh dunia. (1 Yohanes 2:2)

Inilah kasih itu: Bukan kita yang telah mengasihi Allah, tetapi Allah yang telah mengasihi kita dan yang telah mengutus Anak-Nya sebagai pendamaian bagi dosa-dosa kita. (1 Yohanes 4:10)

Pada kedua ayat ini kata "pendamaian" mengacu pada Yesus Kristus. Apabila dicermati dari segi bahasa, kata "pendamaian" pada kalimat "la adalah pendamaian bagi dosa kita ..." merupakan bentukan dari kata "damai" dengan mendapat imbuhan "pe-an" sehingga artinya "orang yang mendamaikan", tetapi dapat juga berarti "proses damai". Dalam 1 Yohanes 2:2 kata "pendamaian" ini terkait dengan kata "pengantara" dalam 1 Yohanes 2:1. Penulis 1 Yohanes memberi semacam penghiburan bagi pembacanya bahwa apabila mereka berbuat dosa, maka Yesus Kristus menjadi pengantara mereka kepada Bapa. Dengan kata lain melalui perantaraan Yesus Kristus terbuka peluang untuk terjadinya pendamaian antara manusia dengan Bapa. Bahkan pada ayat 2 penulis menekankan bahwa karya pendamaian ini disediakan bagi manusia seluruh dunia.

Untuk 1 Yohanes 4:10 kata "pendamaian" lebih cenderung dikaitkan dengan kasih. Mulai 1 Yohanes 4:7 sampai 1 Yohanes 4:21 secara panjang lebar penulis menyebutkan bahwa Yesus sebagai Anak Allah diutus ke dalam dunia sebagai wujud kasih Allah kepada manusia. Allah adalah kasih, maka kasih berasal dari Allah dan karena sifat-Nya ini maka Allah terlebih dahulu mengasihi manusia. Dengan mengutus Anak-Nya ke dalam dunia, Allah menyediakan diri untuk terjadinya pemulihan hubungan antara manusia dengan diri-Nya. Teologi pendamaian yang dirangkum dari teks 1 Yohanes dapat digambarkan dalam bentuk mindmap pada Gambar 2.

Berdasarkan teks 1 Yohanes, yang menjadi inisiator proses damai ini adalah Allah, dengan cara mengutus Yesus Kristus menjadi pengantara (1 Yohanes 2:1) dan juru selamat bagi seluruh umat manusia (1 Yohanes 4:14). Tujuan utama pendamaian adalah pengampunan dosa manusia, karena semua manusia berdosa (1 Yohanes 1:8,9,10) oleh karena telah melanggar hukum Allah (1 Yohanes 3:4) dan melakukan kejahatan (1 Yohanes 5:17). Setelah pendamaian dilakukan oleh Yesus Kristus maka manusia yang menanggapinya akan memperoleh hidup kekal (1 Yohanes 2:25; 3:15; 5:12,13) sehingga akan melihat dan mengenal Allah (1 Yohanes 
3:16). Setelah teologi pendamaian yang terkandung dalam 1 Yohanes 2:2 dan 1 Yohanes 4:10 diuraikan, maka selanjutnya akan didialogkan dengan filosofi ruwatan seperti yang sudah diuraikan sebelumnya.

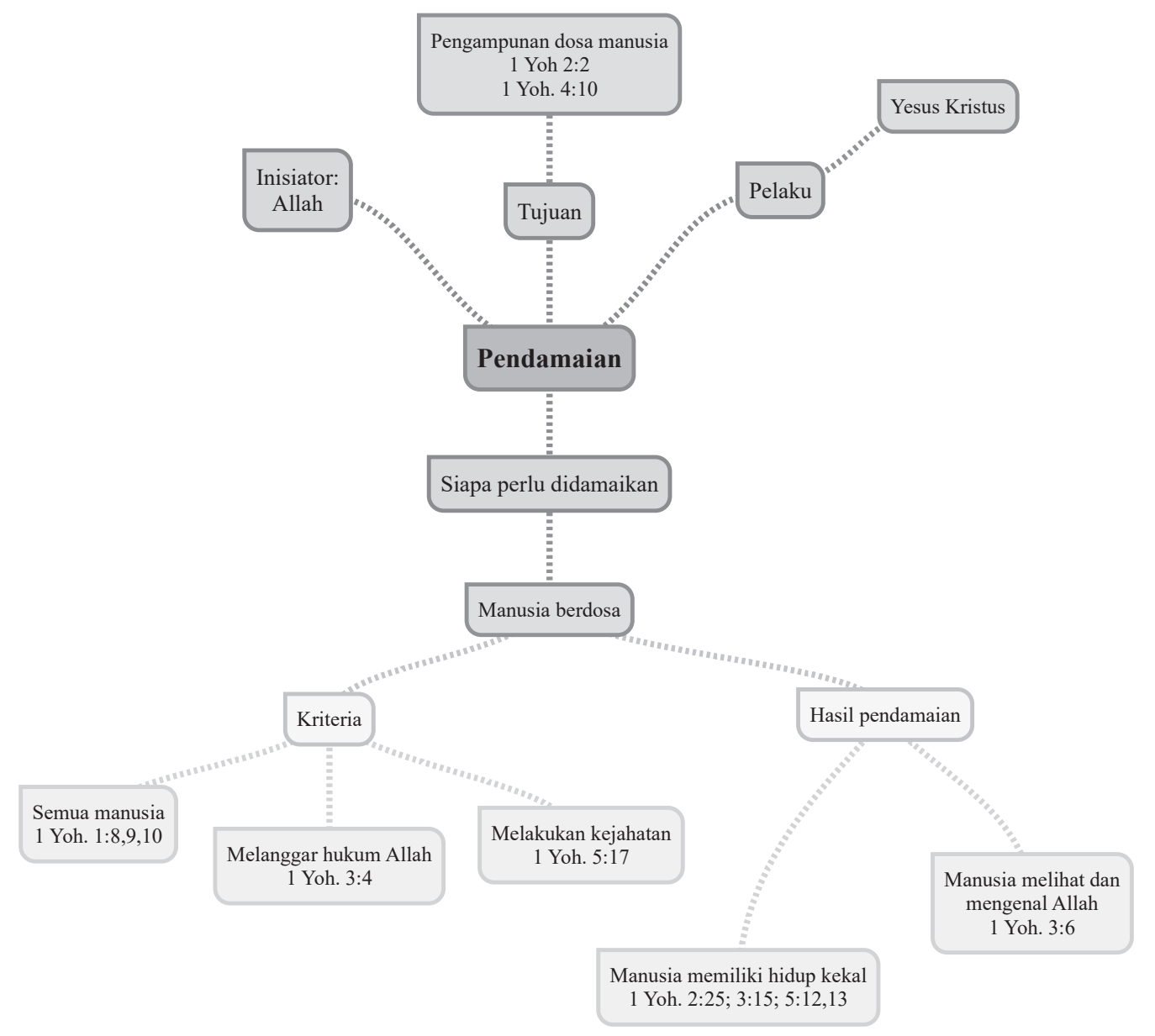

Gambar 2. Mindmap Pendamaian

\section{Mendialogkan Teologi Pendamaian dengan Filosofi Ruwatan}

Dalam beberapa hal teologi pendamaian dalam teks 1 Yohanes dapat dicari kesejajarannya dengan filosofi ruwatan. Namun dermikian dalam mencari kesejajaran ini tidak boleh dengan pendekatan "othak-athik gathuk", yaitu mancari-cari kaitan yang dipaksakan atau dengan memakai asumsi yang berlebihan. Berdasarkan pokok permasalahan yang perlu diselesaikan ada kesejajaran antara konsep dosa dengan sengkala. Dalam 1 Yohanes disebutkan bahwa dosa adalah semua kejahatan dan ketidak taatan manusia atas perintah-perintah Allah. Dipihak lain, sengkala adalah perbuatan manusia yang melanggar larangan atau tabu. Hanya saja cakupan dosa lebih luas dibandingkan dengan aturan tabu yang hanya sedikit. Kalau 
dikaitkan dengan konsep dosa yang diterangkan dalam 1 Yohanes 5:16,17, sengkala ini dapat disejajarkan dengan dosa yang tidak mendatangkan maut. Dosa jenis ini dapat diampuni dan manusia sengkala hanya akan sial dalam hidupnya tetapi masih hidup dan tidak ada kaitannya dengan hidup sesudah mati.

Konsep dosa yang mendatangkan maut dapat disejajarkan dengan manusia sukerta meskipun perlu banyak penjelasan. Dalam 1 Yohanes yang dimaksud dosa yang mendatangkan maut adalah tidak mengakui bahwa Yesus adalah Anak Allah yang datang ke dunia untuk menjadi Juruselamat manusia. Di lain pihak konsep sukerta dalam filosofi ruwatan adalah kriteria yang bukan karena perbuatannya tetapi karena statusnya. Sebaik apapun sifat dan perbuatan seseorang tetapi apabila lahir dengan status sukerta, tetap akan menjadi makanan Batara Kala. Dalam teologi pendamaian, mati yang dimaksud adalah mati kekal, sedangkan dalam folosofi ruwatan hanyalah mati badani karena dimakan Batara Kala.

Jalan keluar atas dosa dalam teologi pendamaian adalah percaya kepada Yesus Kristus, sedangkan jalan keluar bagi para sukerta adalah ritual ruwatan. Tokoh utama dalam 1 Yohanes adalah Yesus Kristus, sedangkan dalam filosofi ruwatan adalah dalang Kanda Buwana. Yesus Kristus adalah Anak Allah yang diutus menjadi Juru Selamat, sedangkan dalang Kanda Buwana adalah penjelmaan Batara Guru.

Dalam teologi pendamaian kesalahan dilakukan oleh manusia, sedang dalam cerita ruwatan yang bersalah sebenarnya adalah Batara Guru. Dalam teks 1 Yohanes dijelaskan bahwa semua manusia telah berdosa, sehingga kalau ada manusia yang mengaku tidak berdosa berarti ia berdusta dan juga membuat Allah berdusta oleh karena Allah menyatakan bahwa semua orang berdosa. Dalam filosofi ruwatan kesalahan terletak pada Batara Guru yang membuat kriteria sukerta maupun sengkala yang akan menjadi makanan Batara Kala. Kriteria sukerta maupun sengkala ini adalah keputusan Batara Guru untuk mengatasi kesalahannya. Keputusan Batara Guru ini sebenarnya merupakan trick untuk melindungi manusia, karena manusia yang termasuk sukerta dan sengkala ada jalan keluarnya, yaitu melalui ruwatan. Batara Guru sendiri yang menjelma menjadi dalang Kanda Buwana yang mampu me-ruwat manusia sukerta dan sengkala, dan sekaligus me-ruwat Batara Kala sehingga hilang sifat raksasanya dan berubah menjadi dewa.

Dalam teks 1 Yohanes dijelaskan bahwa harus ada keputusan dari pihak manusia untuk dapat berdamai dengan Allah Bapa, yaitu dengan percaya bahwa Yesus adalah Kristus, Anak Allah yang diutus kedalam dunia sebagai Juruselamat. Penulis 1 Yohanes secara tegas menyatakan bahwa Yesus adalah Juruselamat bagi dunia, namun keputusan untuk mendapatkan keselamatan ada di pihak manusia. Konsep yang sama sebenarnya juga ada dalam filosofi ruwatan, namun yang membedakan adalah tidak semua manusia masuk kriteria sukerta atau sengkala, sehingga tidak memerlukan bantuan dalang Kanda Buwana. 
Dalam teks 1 Yohanes ditekankan pada banyak ayat bahwa telah terjadi keretakan hubungan antara manusia dengan Allah akibat dosa manusia. Untuk mengembalikan hubungan ini maka perlu adanya tindakan, pemberian atau kompensasi dari manusia kepada Allah. Untuk maksud ini penulis teks 1 Yohanes memberikan pengajaran bahwa tindakan yang dapat dilakukan manusia berdosa adalah menyadarinya, mengakuinya, dan menyenangkan Allah dengan tetap hidup dalam terang dalam arti menuruti perintahperintahNya. Sedangkan bentuk kompensasi yang dapat dilakukan adalah menerima hukuman akibat dosa-dosanya. Dengan demikian manusia seharusnya dihukum karena pada kenyataannya mereka tidak dapat hidup dalam terang dan menuruti perintah-perintah Allah dengan sepenuhnya. Supaya manusia tidak dihukum, Allah Bapa mengutus Anak-Nya menjadi Juru Selamat, menjadi Pengantara dan menjadi hilasmos (pendamaian: pihak yang menjadi juru damai) bagi manusia.

Dengan menggunakan pemahaman ini, maka alur skemanya adalah: manusia berdosa, perlu dihukum, tetapi ada jalan keluar dari hukuman melalui juru damai, yaitu Yesus Kristus Anak Allah yang datang ke dunia menjadi manusia. Di pihak lain pakem cerita ruwatan memiliki alur skema: manusia sukerta mendapat kutuk dan menjadi makanan Batara Kala, tetapi ada jalan keluar yaitu di-ruwat oleh dalang Kanda Buwana yang merupakan penjelmaan dari Batara Guru. Dengan memperhatikan kedua alur tersebut, maka untuk mendialogkan teks 1 Yohanes dengan teks ruwatan dapat memakai link konsep dosa dan konsep sukerta beserta jalan keluarnya.

Sejak awal teks, penulis 1 Yohanes sudah menyinggung tentang dosa, yaitu fakta bahwa penulis dan penerima teks, yang diwakili dengan kata ganti "kita" telah berdosa. Untuk itu seandainya mereka tidak mengakui dosa itu, maka ada dua konsekwensinya, pertama, menipu diri sendiri dan tidak memiliki kebenaran (1:8), kedua, membuat Dia pendusta dan firman-Nya tidak ada dalam mereka (1:10).

Setelah penulis menyadarkan atau mengingatkan pembacanya bahwa mereka telah berdosa, maka ia menunjukkan jalan keluar yang tersedia untuk mengatasi dosa tersebut. Jalan keluar pertama adalah melalui karya Yesus Kristus dan jalan keluar kedua adalah melalui tindakan nyata dalam kehidupan orang yang percaya kepada Yesus Kristus. Karya Yesus Kristus diuraikan pada setiap pasal, yang meliputi menyucikan dosa (1:7), menjadi pengantara (2:1), menjadi pendamaian $(2: 2 ; 4: 10)$, menghapus segala dosa (3:5), menyerahkan nyawa-Nya (3:16), menjadi Juruelamat (4:14) dan melindungi dari yang jahat $(5: 18)$.

Fakta bahwa mereka berdosa tidak perlu dipungkiri, namun kabar gembira yang disampaikan oleh penulis adalah bahwa mereka mempunyai Yesus Kristus yang telah menyerahkan nyawa-Nya untuk menghapus dosa tersebut. Lebih dari itu Yesus Kristus bertindak sebagai Pengantara, Juru Selamat dan Juru Damai antara manusia berdosa dengan Allah. 
Dalam tradisi ruwatan ada dua macam penyebab orang terkena kutuk yaitu sukerta dan sengkala, meskipun dalam pembicaaan sehari-hari keduanya dianggap sama. Secara logika hampir semua orang termasuk kriteria sukerta berdasarkan jumlah anak kandung dalam suatu keluarta. Terlebih di jaman sekarang ini ketika jumlah anak kandung pada umumnya kurang dari lima orang maka peluang menjadi sukerta cukup besar. Kategori sengkala juga memiliki banyak kemungkinan, meskipun untuk jaman sekarang peluang tersebut semakin berkurang. Sebagian besar penyebab sengkala adalah melakukan hal yang tabu baik secara sengaja maupun tidak sengaja. Pada jaman sekarang, barang-barang yang memungkinkan seseorang berbuat kesalahan tersebut semakin langka, misalnya pipisan, gandhik, tutup keyong rumah, lesung, dan lain-lain. Untuk semua orang yang masuk dalam kriteria sukerta maupun sengkala ada jalan keluar supaya terbebas dari kutuk, yaitu melalui upacara ruwatan. Upacara ini diadakan dengan pementasan wayang kulit oleh dalang tertentu di rumah orang yang akan di-ruwat.

\section{Penutup}

Tradisi ruwatan masih dapat dijumpai di beberapa daerah, khususnya Jawa Tengah, Yogyakarta dan Jawa Timur, meskipun penyelenggaranya bukan perorangan tetapi suatu lembaga atau institusi tertentu dalam bentuk ruwatan masal. Tradisi ini pada umumnya diadakan pada bulan Sura dalam kalender Jawa. Orang Kristen yang bertempat tinggal dan bergaul dengan masyarakat yang masih mengadakan tradisi ruwatan mau tidak mau harus berbaur dengan mereka. Berdasarkan analisis dalam tulisan ini, ada peluang bagi orang Kristen untuk dapat memahami bahkan menerima apa yang mereka yakini terkait ruwatan.

Ritual ruwatan memang terkesan mistis, terutama terkait adanya sesaji dan mantramantra. Namun kalau dicermati filosofinya, sesaji adalah simbol-simbol yang diharapkan dapat dipetik maknanya untuk kebaikan. Selain itu, mantra-mantra yang terkesan mistis, kalau dicermati isi dan maknanya sebenarnya kalimat-kalimat mantra tersebut berupa cerita atau kisah terjadinya Batara Kala, yang ditulis dengan bahasa Kawi atau Jawa Kuno.

Teks 1 Yohanes khususnya 1 Yohanes 2:2 dan 1 Yohanes 4:10 secara eksplisit memakai kata "pangruwat" untuk padanan kata "pendamaian" pada diri Yesus Kristus. Dengan demikian orang Jawa Kristen seharusnya tidak perlu alergi dengan istilah tersebut. Terlebih ketika memahami bahwa karya Yesus Kristus bagi umat manusia jauh lebih besar dibandingkan dengan konsep ruwatan. Memaknai karya Yesus dengan istilah "pangruwat" tidak akan mengurangi makna penebusan-Nya bagi dunia. 


\section{Tentang Penulis}

Sri Suwarno, lahir di Klaten, tahun 1959. Asal gereja GKJ Sabda Mulya, Kartasura. Bekerja sebagai pengajar tetap sebagai dosen Informatika UKDW, mengikuti Program Magister IImu Teologi, dengan Minat Studi Kependetaan (M.Div.) pada Fakultas Teologi Universitas Kristen Duta Wacana (UKDW) Yogyakarta. Bidang yang ditekuni sekarang adalah mengajar informatika biometrik, khususnya sidik jari, dan bidang teologi kontekstual (khususnya dalam konteks budaya Jawa).E-mail: sswn@staff.ukdw.ac.id

\section{Daftar Pustaka}

Buku:

Brata, Pr., Sandiwan, A., Tatacara Katolik, II, dalam Kustono, H.A., 2006. "Ruwatan: Tinjauan Alkitabiah", h. 77-78.

Kristiyanto. 2002. Yesus Kristus Juru Ruwat Manusia, Sebuah Studi Semiotik Terhadap Teks "Ruwatan" Murwakala dalam Serat Centhini serta Implikasinya bagi Gereja-gereja Kristen Jawa, Tesis S2 Program Pasca Sarjana Teologi, Yogyakarta: Universitas Kristen Duta Wacana.

Kustono, H.A. 2006. "Ruwatan: Tinjauan Alkitabiah", Studia Philosophica et Theologica, Vol. 6 No. 1, Maret, 2006, h. 75-77.

Relin, D.E. 2015. Aktualisasi Tradisi Ruwatan pada Masyarakat Jawa: Kajian Filosofis, Denpasar: Ashram Gandhi Puri, Indra Udayana Institute of Vedanta, h. 72-73.

Rusdy, S.T. 2012. Ruwatan Sukerta dan Ki Timbul Hadiprayitno, Jakarta: Yayasan Kertagama, h. 65-130.

Subalinata, R.S, dkk. 1985. Sejarah dan Perkembangan Cerita Murwakala dan Ruwatan dari Sumber-sumber Sastra Jawa, Jakarta: Departemen Pendidikan dan Kebudayaan Direktorat Jendral Kebudayaan Proyek Penelitian dan Pengkajian Kebudayaan Nusantara (Javanologi), h. 34-40.

Subalinata, R.S, dkk. 1985. Sejarah dan Perkembangan Cerita Murwakala dan Ruwatan dari Sumber-sumber Sastra Jawa, Jakarta: Departement Pendidikan dan Kebudayaan Direktorat Jendral Kebudayaan Proyek Penelitian dan Pengkajian Kebudayaan Nusantara (Javanologi), h. 45-87. 


\section{Journal of Divinity, Peace and Conflict Studies . Iradha}

Tim Balai Bahasa Yogyakarta. 2011. Kamus Bahasa Jawa (Bausasta Jawa), Yogyakarta: Penerbit Kanisius, h.628.

Website:

https://www.kbbi.web.id/ruwat 
